\title{
Addition of Vertical Enrichment Structures Does Not Improve Growth of Three Salmonid Species during Hatchery Rearing
}

\author{
Sarah C. White², Michael E. Barnes ${ }^{1 *}$, Eric Krebs ${ }^{1}$, Nathan Huysman¹, Jill M. Voorhees ${ }^{1}$
}

${ }^{1}$ Department of Game, Fish, and Parks, McNenny State Fish Hatchery, 19619 Trout Loop, Spearfish, South Dakota

${ }^{2}$ Benedictine College, $1020 \mathrm{~N} 2^{\text {nd }}$ Street, Atchison, Kansas

*Corresponding author: Michael E. Barnes, Department of Game, Fish, and Parks, McNenny State Fish Hatchery, 19619 Trout Loop, Spearfish, South Dakota, Tel: 1-605-642-6920; E-mail: mike.barnes@state.sd.us

\begin{abstract}
Environmental enrichment is the placement of structure or other modifications in typically sterile hatchery rearing units. This study investigated the use of vertically-suspended aluminum rod arrays in covered circular tanks on the rearing performance of brown trout (Salmo trutta), Chinook salmon (Oncorhynchus tshawytscha), and Atlantic salmon (Salmo salar) in separate trials lasting 59, 78, and 125 days respectively. No significant differences were observed in gain, feed conversion ratio, individual fish total length, or individual fish weight between the enriched and unenriched treatments in any of the three trials. In addition, vertically-suspended structure had no significant effect on Atlantic salmon relative fin length. These experiments are the first to indicate no benefits during the rearing of salmonids using vertically-suspended enrichment.
\end{abstract}

\section{Introduction}

Environmental enrichment is the deliberate addition of materials or structures to otherwise sterile hatchery rearing units in order to potentially improve fish behavior, growth, and post stocking survival ${ }^{[1]}$. However, hatchery rearing units are typically devoid of internal structures to facilitate routine cleaning and other animal husbandry actions, and, in the case of circular tanks, the continuous removal of fish waste by rotational velocities ${ }^{[2-6]}$. Some enrichment techniques previously studied have consisted of woody or stony debris, plant or root material, plastic plants, or concrete blocks added to hatchery tanks ${ }^{[6-13]}$. However, despite their potential benefits, these types of enrichment features may trap food and feces or harbor pathogens, increasing the risk of disease or interfering with self-cleaning in circular tanks ${ }^{[14,15]}$.

Kientz and Barnes ${ }^{[16]}$ and Kientz et al. ${ }^{[17]}$ described an environmental enrichment technique using metal rods or strings of balls suspended from the top of circular tanks. The vertically-suspended rod arrays did not interfere with the self-cleaning nature of the tanks, and required no additional labor during normal hatchery rearing compared to unenriched tanks. They were also shown to improve the growth and feed conversion ratio of rainbow trout (Oncorhynchus mykiss ${ }^{[16,17]}$.
No studies have been published examining the effect of vertically-suspended environmental enrichment on species other than rainbow trout. Thus, the objective of this study was to evaluate the rearing performance of brown trout (Salmo trutta), Chinook salmon (Oncorhynchus tshawytscha), and Atlantic salmon (Salmo salar) reared in the presence or absence of vertically-suspended rod arrays.

Received date: August 29, 2018

Accepted Date: November 09, 2018

Published Date: November 14, 2018

Citation: White, S. C. Addition of Vertical Enrichment Structures Does Not Improve Growth of Three Salmonid Species during Hatchery Rearing. (2018) J Marine Biol Aquacult 4(1): 48- 52 .

Copy Rights: (C) 2018 Barnes, M.E. This is an Open access article distributed under the terms of Creative Commons Attribution 4.0 International License. 


\section{Methods}

\section{Methods common to all experiments}

All experiments were conducted at McNenny State Fish Hatchery, rural Spearfish, South Dakota, USA using degassed and aerated well water at a constant temperature of $11^{\circ} \mathrm{C}$ (water hardness as $\mathrm{CaCO}_{3}=360 \mathrm{mg} / \mathrm{L}$, alkalinity as $\mathrm{CaCO}_{3}=210 \mathrm{mg} / \mathrm{L}$, $\mathrm{pH}=7.6$, total dissolved solids $=390 \mathrm{mg} / \mathrm{L}$ ). Tanks, rather than individual fish, were used as the experimental units. In each experiment, six circular tanks (diameter $=1.82 \mathrm{~m}$, height $=0.80 \mathrm{~m}$, water depth $=0.59 \mathrm{~m})$ were used $(\mathrm{n}=3)$, with two different treatments assigned: barren control tanks and tanks with added structural enrichment. All tanks were near-fully covered by corrugated plastic overhead covers ${ }^{[18-20]}$. Control tanks were devoid of any in-tank environmental enrichment structures, while experimental tanks included vertically-suspended linear enrichment structures described by Kientz and Barnes ${ }^{[17]}$. These enrichment structures consisted of an array of nine aluminum rods (diameter $=0.95 \mathrm{~cm}$, length $=57.15 \mathrm{~cm}$ ) protruding downwards into each tank from attachment points on the overhead covers. The rods were approximately evenly spaced at an average distance of 11.0 $\mathrm{cm}$ from each other, arranged in an array with an area of $15 \mathrm{~cm}$ $\mathrm{x} 40 \mathrm{~cm}$. The array was situated at an average distance of 26.7 $\mathrm{cm}$ from the edge of the tank, on the side opposite the spray bar from which water entered the tank (Figure 1).

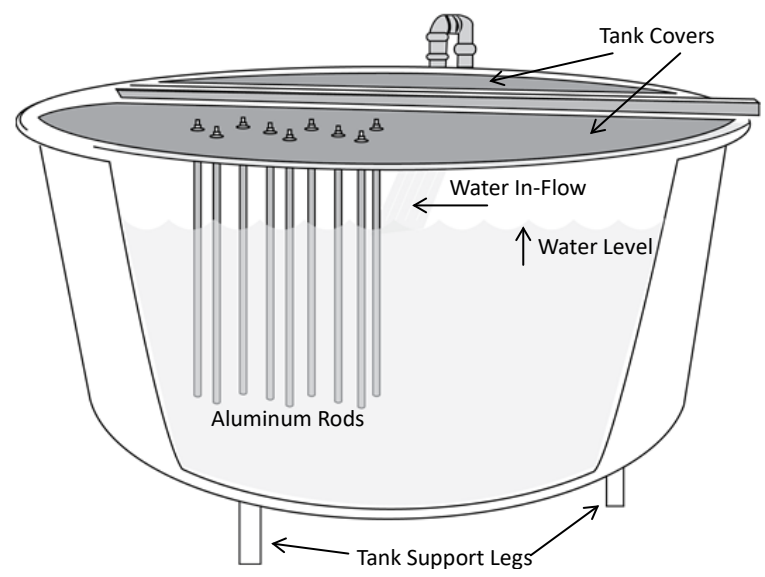

Figure 1: Schematic of an environmentally-enriched (aluminum rods added) circular rearing tank ( $1.8 \mathrm{~m}$ diameter and $0.8 \mathrm{~m}$ deep).

For each experiment, fish from a common pool were evenly divided by weight into the six tanks. All fish were fed daily at 20 minute intervals during daylight hours using automatic rotating feeders. Feeding rates at or slightly above satiation were determined for each experiment by the hatchery constant meth$\operatorname{od}^{[21]}$.

\section{Experiment 1 - brown trout}

This experiment used juvenile brown trout and ran from March 4, 2016, to May 2, 2016 (59 days). Before the fish were divided into the six tanks, 30 randomly sampled individual fish were weighed and measured. Mean (SE) starting total length was 64(1) $\mathrm{mm}$, and starting weight was $2.6(0.1) \mathrm{g}$. Approximately 2,500 fish $(5.74 \mathrm{~kg})$ were placed into each of the six tanks at the start of the experiment. The trout were fed $1.5 \mathrm{~mm}$ extruded floating classic trout feed (Skretting, Tooele, Utah, USA), at a projected growth rate of $0.060 \mathrm{~cm}$ per day and a planned feed conversion of 1.1. At the conclusion of the experiment, total tank weight was recorded to the nearest $0.01 \mathrm{~kg}$, with five randomly sampled fish from each tank individually weighed to the nearest $\mathrm{g}$, and total length measured to the nearest $\mathrm{mm}$.

\section{Experiment 2 - fall Chinook salmon}

This experiment used juvenile landlocked fall Chinook salmon and ran from March 3, 2016 to May 20, 2016 (78 days). Before the fish were divided into the six tanks, 30 randomly sampled individual fish were weighed and measured. Mean (SE) starting total length was 69 (1) $\mathrm{mm}$ and starting weight was $2.8(0.1) \mathrm{g}$. Approximately 2,000 fish $(5.28 \mathrm{~kg})$ were placed into each of the six tanks at the start of the experiment. The salmon were fed $1.0 \mathrm{~mm}$ extruded slow-sinking salmon feed (Skretting, Tooele, Utah, USA), using amounts based on a projected growth rate of $0.070 \mathrm{~cm}$ per day and a planned feed conversion of 1.1 . Final total tank weight was recorded to the nearest $0.01 \mathrm{~kg}$ at the conclusion of the experiment, with five randomly sampled fish from each tank individually weighed to the nearest $\mathrm{g}$, and total length measured to the nearest $\mathrm{mm}$.

\section{Experiment 3 - Atlantic salmon}

This experiment used juvenile Atlantic salmon and ran from January 19, 2018 to May 24, 2018 (125 days). Before the fish were divided into the six tanks, 20 randomly sampled fish were individually weighed and measured. Mean (SE) starting total length was 125 (3) cm, and starting weight was 19.8 (1.5) g. Approximately 360 fish $(7.18 \mathrm{~kg})$ were placed into each of the six tanks at the start of the experiment. The salmon were fed 1.0 mm BioVita feed (Bio Oregon, Longview, Washington, USA). Mortalities were recorded throughout the experiment and mortality percentage was calculated for each tank. Final total tank weight was recorded to the nearest $0.01 \mathrm{~kg}$ at the conclusion of the experiment, with five randomly sampled fish from each tank individually weighed to the nearest $g$, and total length measured to the nearest $\mathrm{mm}$. Pectoral and dorsal fin lengths were measured to the nearest $0.1 \mathrm{~mm}$.

\section{Calculations and Statistics}

Total tank weight gain was calculated for each population using the following equation: Gain = final tank weight - initial tank weight. Feed conversion ratio (FCR) was calculated according to the equation: $\mathrm{FCR}=$ total feed fed to tank / total tank weight gain. The condition factor $(\mathrm{K})$ for individual fish was calculated using the following equation: $\mathrm{K}=10^{5} \mathrm{x}$ [weight / (body length) ${ }^{3}$ ]. In the Atlantic salmon experiment, relative fin lengths were calculated using the following equation: fin index $=100 \mathrm{x}$ fin length / body length.

Data for all three experiments were analyzed using the SPSS (24.0) statistical analysis program (Systat Software, Inc., Chicago, Illinois, USA). One-way Analysis of Variance (ANOVA) was conducted to analyze the tank data. Because the tanks were considered the experimental units, not individual fish, nested ANOVA was conducted on the individual fish data. Significance was pre-determined at $P<0.05$. 


\section{Results}

\section{Experiment 1 - brown trout}

There were no significant differences in total tank ending weight, weight gain, or feed conversion ratio between fish reared either with or without the vertically-suspended rod arrays (Table 1). There were also no significant differences in individual fish lengths, weights, orcondition factors between treatments(Table2).

Table 1: Mean ( \pm SE) tank weights, gains, food fed, and feed conversion ratios $\left(\mathrm{FCR}^{\mathrm{a}}\right)$ for brown trout, Chinook salmon, and Atlantic salmon reared with or without enrichment structures $(n=3)$.

\begin{tabular}{|c|c|c|c|c|}
\hline Species & Variable & Control & Structures & P-value \\
\hline \multirow{6}{*}{$\begin{array}{l}\text { Brown } \\
\text { trout }\end{array}$} & Rearing days & 59 & 59 & \\
\hline & Initial weight $(\mathrm{kg})$ & $5.74 \pm 0.00$ & $5.74 \pm 0.00$ & \\
\hline & Final weight (kg) & $47.45 \pm 0.06$ & $47.95 \pm 0.78$ & 0.556 \\
\hline & Gain (kg) & $41.71 \pm 0.06$ & $42.21 \pm 0.78$ & 0.556 \\
\hline & Food fed (kg) & $37.17 \pm 0.00$ & $37.17 \pm 0.00$ & \\
\hline & FCR & $0.89 \pm 0.001$ & $0.88 \pm 0.02$ & 0.580 \\
\hline \multirow{6}{*}{$\begin{array}{l}\mathrm{C} \text { h i - } \\
\mathrm{n} \text { o o k } \\
\text { salmon }\end{array}$} & Rearing days & 78 & 78 & \\
\hline & Initial weight $(\mathrm{kg})$ & $5.28 \pm 0.00$ & $5.28 \pm 0.00$ & \\
\hline & Final weight (kg) & $30.99 \pm 1.88$ & $32.88 \pm 0.44$ & 0.382 \\
\hline & Gain $(\mathrm{kg})$ & $25.71 \pm 1.88$ & $27.60 \pm 0.44$ & 0.382 \\
\hline & Food fed (kg) & $28.00 \pm 0.00$ & $28.00 \pm 0.00$ & \\
\hline & FCR & $1.10 \pm 0.08$ & $1.02 \pm 0.02$ & 0.336 \\
\hline \multirow{7}{*}{$\begin{array}{l}\text { A t - } \\
\text { lantic } \\
\text { salmon }\end{array}$} & Rearing days & 125 & 125 & \\
\hline & Initial weight $(\mathrm{kg})$ & $7.18 \pm 0.00$ & $7.18 \pm 0.00$ & \\
\hline & Final weight $(\mathrm{kg})$ & $73.46 \pm 0.32$ & $75.42 \pm 1.01$ & 0.137 \\
\hline & Gain (kg) & $66.28 \pm 0.32$ & $68.24 \pm 1.01$ & 0.137 \\
\hline & Food fed (kg) & $81.35 \pm 0.00$ & $81.35 \pm 0.00$ & \\
\hline & FCR & $1.23 \pm 0.01$ & $1.19 \pm 0.02$ & 0.138 \\
\hline & Mortality (\%) & $3.03 \pm 0.28$ & $3.58 \pm 0.42$ & 0.335 \\
\hline
\end{tabular}

${ }^{\text {a }}$ FCR $=$ Feed Conversion Ratio $=$ total food fed $/$ tank gain

Table 2: Mean ( \pm SE)individual fish total lengths, weights, and condition factors $\left(\mathrm{K}^{\mathrm{a}}\right)$ values for brown trout, Chinook salmon, and Atlantic salmon, and Atlantic salmon relative fin lengths (\%) reared with or without enrichment structures $(n=3)$.

\begin{tabular}{|l|l|l|l|l|}
\hline Species & Variable & Control & Structures & P-value \\
\hline \multirow{3}{*}{$\begin{array}{l}\text { B r o w n } \\
\text { trout }\end{array}$} & Length $(\mathrm{mm})$ & $94 \pm 2$ & $90 \pm 1$ & 0.090 \\
\cline { 2 - 5 } & Weight $(\mathrm{g})$ & $9.7 \pm 0.4$ & $8.8 \pm 0.5$ & 0.219 \\
\cline { 2 - 5 } & $\mathrm{K}^{\mathrm{a}}$ & $1.16 \pm 0.03$ & $1.20 \pm 0.05$ & 0.602 \\
\hline \multirow{3}{*}{$\begin{array}{l}\text { Chinook } \\
\text { salmon }\end{array}$} & Length $(\mathrm{mm})$ & $113 \pm 5$ & $116 \pm 4$ & 0.656 \\
\cline { 2 - 5 } & Weight $(\mathrm{g})$ & $15.6 \pm 2.3$ & $16.7 \pm 2.0$ & 0.755 \\
\cline { 2 - 5 } & $\mathrm{K}$ & $1.08 \pm 0.01$ & $1.06 \pm 0.02$ & 0.390 \\
\hline \multirow{3}{*}{$\begin{array}{l}\text { Atlantic } \\
\text { salmon }\end{array}$} & Length $(\mathrm{mm})$ & $271 \pm 13$ & $267 \pm 6$ & 0.812 \\
\cline { 2 - 5 } & Weight $(\mathrm{g})$ & $230.1 \pm 34.3$ & $208.8 \pm 11.7$ & 0.589 \\
\cline { 2 - 5 } & $\mathrm{K}$ & $1.14 \pm 0.01$ & $1.10 \pm 0.03$ & 0.192 \\
\cline { 2 - 5 } & Pectoral fin $(\%)^{\mathrm{b}}$ & $9.43 \pm 0.17$ & $9.32 \pm 0.32$ & 0.777 \\
\cline { 2 - 5 } & Dorsal fin $(\%)^{\mathrm{c}}$ & $3.50 \pm 0.21$ & $3.50 \pm 0.20$ & 0.993 \\
\hline
\end{tabular}

${ }^{\mathrm{a}} \mathrm{K}=$ condition factor $=10^{5} \mathrm{x}$ weight $/$ total length $^{3}$

${ }^{\text {bPectoral }}$ fin $(\%)=100 \times$ pectoral fin length / total length

'Dorsal fin $(\%)=100 \mathrm{x}$ dorsal fin length / total length

\section{Experiment 2 - fall Chinook salmon}

Total tank ending weight, weight gain, and feed conversion ratio were not significantly different between fish reared either with or without the vertically-suspended rod arrays. Individual fish lengths, weights, and condition factors were also not significantly different.

\section{Experiment 3 - Atlantic salmon}

There were no significant differences in total tank ending weights, weight gain, feed conversion ratio, or mortality between fish reared either with or without the vertically-suspended rod arrays. There were also no significant differences in individual fish lengths, weights, condition factors, or any fin indices between the treatments.

\section{Discussion}

These results of the three experiments in this study are contrary to the findings of Kientz and Barnes ${ }^{[16]}$ and Kientz et al. ${ }^{[17]}$, who found significant improvements in rainbow trout rearing performance when vertically-suspended environmental enrichment structures similar to those used in this study were added to circular tanks. Thus, this difference may be due to inter-species difference. Näslund and Johnsson ${ }^{[1]}$ noted that the effects of enrichment have been inconsistent among species, and enrichment techniques may need to be adapted according to species-specific considerations.

Study duration may also have influenced the results of these experiments. Although the experiment using Atlantic salmon lasted 125 days, brown trout and Chinook salmon were only in the presence of enrichment structures for 59 and 78 days, respectively. This may be too short of a time for differences to become apparent. Brockmark et al. ${ }^{[11]}$ found no improvement in Atlantic salmon growth after 123 rearing days when structure was added to rearing tanks, but did observe improvement by 311 rearing days.

Based on the extremely low feed conversion ratio of the brown trout in this study, it is possible that they were underfed. Decreased feed conversion ratios have been observed in juvenile Turbot (Scophthalmus maximus L.) subjected to feed restriction $^{[22,23]}$. If the brown trout in this study were underfed, fish from both treatments may have been forced to use feed more efficiently, thereby decreasing the potential for improvement in feed conversion ratio with the addition of enrichment structures to the tanks. In addition, stress may have caused the fish in this study to react differently to enrichment than fish fed to satiation; increased oxidative stress has been shown in brown trout subjected to long-term feed restriction ${ }^{[24]}$.

The lack of significant improvement in fin condition in the Atlantic salmon reared with environmental enrichment in this study may indicate that the control tank rearing environments were also of high quality. In previous studies, enrichment has been shown to decrease fin damage in steelhead trout and Atlantic salmon ${ }^{[10,25]}$. However, if fins of fish from both treatments in this study remained in good condition, the opportunity for enrichment to improve fin condition would be diminished.

This study focused on fish growth and feeding efficiency. Although positive results on fish growth were not observed, it is possible that environmental enrichment may have affected 
fish physiology. Millidine et al. ${ }^{[26]}$ reported reductions in resting heart rate in fish in enriched tanks. Future studies should evaluate physiological effects, as well as the easily observed growth metrics, in a variety of fish species.

Acknowledgements: We thank Patrick Nero, Kelsen Young, Tristan Blain, Tim Palmer, and Nathan Winter for their assistance with this study.

\section{References}

1. Näslund, J., Johnsson, J.I. Environmental enrichment for fish in captive environments: effects of physical structures and substrates. (2016) Fish Fisheries 17(1): 1-30.

Pubmed | Crossref | Others

2. Tvinnereim, K., Skybakmoen, S. Water exchange and self-cleaning in fish-rearing tanks. (1989) Aquac: Biotech Prog 2: 597-1222.

Pubmed $\mid$ Crossref $\mid$ Others

3. Timmons, M.B., Summerfelt, S.T., Vinci, B.J. Review of circular tank technology and management. (1998) Aquac Eng 18(1):51-69.

Pubmed | Crossref | Others

4. Oca, J., Masalo, I. Design criteria for rotating flow cells in rectangular aquaculture tanks. (2007) Aquac Eng 36(1): 3644.

Pubmed $\mid$ Crossref $\mid$ Others

5. Oca, J., Masalo, I. Flow pattern in aquaculture circular tanks: Influence of flow rate, water depth, and water inlet and outlet features. (2012) Aquac Eng 52: 65-72.

Pubmed $\mid$ Crossref $\mid$ Others

6. Krebs, J., Crank, K.M., Krebs, E., et al. Use of bottom structure and tank cover during rainbow trout rearing in circular tanks. (2017) J Fish Livest Prod 5(3): 247.

Pubmed | Crossref | Others

7. Berejikian, B.A., Smith, R.J.F., Tezak, E.P., et al. Chemical alarm signals and complex hatchery rearing habitats affect antipredator behavior and survival of Chinook salmon Oncorhynchus tshawytscha juveniles. (1999) Can J Fish Aquat Sci 56(5): 830-838.

Pubmed $\mid$ Crossref $\mid$ Others

8. Berejikian, B.A., Tezak, E.P., Flagg, T.A., et al. Social dominance, growth, and habitat use of age-0 steelhead Oncorhynchus mykiss grown in enriched and conventional hatchery rearing environments. (2000) Can J Fish Aquat Sci 57(3): 628-636.

Pubmed $\mid$ Crossref $\mid$ Others

9. Brown, C., Davidson, T., Laland, K. Environmental enrichment and prior experience of live prey improve foraging behaviour in hatchery-reared Atlantic salmon. (2003) J Fish Biol 63(Supplement A): 187-196.

Pubmed | Crossref | Others

10. Berejikian, B.A., Tezak, E.P. Rearing in enriched hatchery tanks improves dorsal fin quality of juvenile steelhead. (2005) N Am J Aqua 67: 289-293.

Pubmed | Crossref | Others

11. Brockmark, S., Neregård, L., Bohlin,T., et al. Effects of rearing density and structural complexity on pre- and post-release performance of Atlantic salmon. (2007) Trans
Am Fish Soc 136(5): 1453-1462.

Pubmed | Crossref | Others

12. Fast, D.E., Neeley, D., Lind, D.T., et al. Survival comparison of spring Chinook salmon reared in a production hatchery under optimum conventional and seminatural conditions. (2008) Trans Am Fish Soc 137: 1507-1518.

Pubmed $\mid$ Crossref $\mid$ Others

13. Bergendahl, A.I., Miller, S., Depasquale, C., et al. Becoming a better swimmer: structural complexity enhances agility in captive-reared fish. (2017) J Fish Biol 90: 1112-1117. Pubmed $\mid$ Crossref $\mid$ Others

14. Baynes, S.M., Howell, B.R. Observations on the growth, survival and disease resistance of juvenile common sole, Solea solea L. (1993) Aquac Fish Man 24: 95-100.

Pubmed $\mid$ Crossref $\mid$ Others

15. Tuckey, L.M., Smith, T.I. Effects of photoperiod and substrate on larval development and substrate preference of juvenile southern flounder, Paralichthys lethostigma. (2001) J Appl Aquac 11: 1-20.

Pubmed | Crossref | Others

16. Kientz, J., Barnes, M.E. Structural complexity improves the rearing performance of Rainbow Trout in circular tanks. (2016) N Am J Aquac 78: 203-207.

Pubmed $\mid$ Crossref $\mid$ Others

17. Kientz, J., Crank, K.M., Barnes, M.E. Enrichment of circular tanks with vertically suspended strings of colored balls improves rainbow trout rearing performance. (2018) N Am J Aquac 80(2): 162-167.

Pubmed | Crossref | Others

18. Barnes, M.E., Durben, D.J. Use of partial tank covers during hatchery rearing of feral rainbow trout. (2003) N Am J Aquac 65: 344-348.

Pubmed | Crossref $\mid$ Others

19. Barnes, M.E., Miller, J., Durben, D.J. Partial overhead tank cover use during feral brown trout rearing. (2005) N Am J Aquac 67: 319-323.

Pubmed | Crossref | Others

20. Walker, L.M., Parker, T.M., Barnes, M.E. Full and partial overhead tank cover improves rainbow trout rearing performance. (2016) N Am J Aquac 78(1): 20-24.

Pubmed $\mid$ Crossref $\mid$ Others

21. Buterbaugh, G.L., Willoughby, H. A feeding guide for brook, brown, and rainbow trout. (1967) Prog Fish-Cult 29: 210-215.

Pubmed $\mid$ Crossref $\mid$ Others

22. Van Ham, E.H., Berntssen, M.H.G., Imsland, A.K., et al. The influence of temperature and ration on growth, feed conversion, body composition and nutrient retention of juvenile turbot (Scophthalmus maximus). (2003) Aquac 217(1-4): 547-558.

Pubmed $\mid$ Crossref $\mid$ Others

23. Blanquet, I., Oliva-Teles, A. Effect of feed restriction on the growth performance of turbot (Scophthalmus maximus L.) juveniles under commercial rearing conditions. (2010) Aquac Res 41: 1255-1260.

Pubmed | Crossref | Others

24. Bayir, A., Sirkecioglu, A.N., Bayir, M., et al. Metabolic responses to prolonged starvation, food restriction, and refeeding in the brown trout, Salmo trutta: Oxidative stress 
and antioxidant defenses. (2011) Comp Biochem Physiol

Part B: Biochem Mol Biol 159:191-196.

Pubmed $\mid$ Crossref $\mid$ Others

25. Persson, L., Alanara, A. The effect of shelter on welfare of juvenile Atlantic salmon Salmo Salar reared under a feed restriction regimen. (2014) J Fish Biol 85(3): 645-656.

Pubmed $\mid$ Crossref $\mid$ Others

26. Millidine, K.J., Armstrong, J.D., Metcalfe, N.B. Presence of shelter reduces maintenance metabolism of juvenile salmon.(2006) Funct Ecol 20(5): 839-845.

Pubmed | Crossref | Others

Submit your manuscript to Ommega Publishers and we will help you at every step:

- We accept pre-submission inquiries

- Our selector tool helps you to find the most relevant journal

- We provide round the clock customer support

- Convenient online submission

- Thorough peer review

- Inclusion in all major indexing services

- Maximum visibility for your research

Submit your manuscript at

https://www.ommegaonline.org/submit-manuscript 